Article

\title{
Extreme Weather Events and Climate Variability Provide a Lens to How Shallow Lakes May Respond to Climate Change
}

\author{
Karl Havens ${ }^{1,2, *}$, Hans Paerl ${ }^{3}$, Edward Phlips ${ }^{2}$, Mengyuan Zhu ${ }^{4}$, John Beaver ${ }^{5}$ and \\ Akeapot Srifa ${ }^{6}$ \\ 1 Florida Sea Grant College Program, University of Florida, 803 McCarty Drive, Gainesville, FL 32611, USA \\ 2 University of Florida Institute for Food and Agricultural Sciences, School of Forest Resources and Conservation, \\ 7922 NW 71st Street, Gainesville, FL 32653, USA; phlips@ufl.edu \\ 3 Institute of Marine Sciences, University of North Carolina at Chapel Hill, 3431 Arendell Street, \\ Morehead City, NC 28557, USA; hans_paerl@unc.edu \\ 4 State Key Laboratory of Lake Science and Environment, Nanjing Institute of Geography and Limnology, \\ Chinese Academy of Sciences, 73 East Beijing Road, Nanjing 210008, China; myzhu@niglas.ac.cn \\ 5 BSA Environmental Services, Inc., 23400 Mercantile Rd, Beachwood, OH 44122, USA; j.beaver@bsaenv.com \\ 6 Department of Biology, Mahasarakham University, Mahasarakham 44150, Thailand; akesrifa@gmail.com \\ * Correspondence: khavens@ufl.edu; Tel.: +352-392-5870
}

Academic Editors: Erik Jeppesen and Martin Søndergaard

Received: 17 March 2016; Accepted: 25 May 2016; Published: 28 May 2016

\begin{abstract}
Shallow lakes, particularly those in low-lying areas of the subtropics, are highly vulnerable to changes in climate associated with global warming. Many of these lakes are in tropical cyclone strike zones and they experience high inter-seasonal and inter-annual variation in rainfall and runoff. Both of those factors strongly modulate sediment-water column interactions, which play a critical role in shallow lake nutrient cycling, water column irradiance characteristics and cyanobacterial harmful algal bloom (CyanoHAB) dynamics. We illustrate this with three examples, using long-term (15-25 years) datasets on water quality and plankton from three shallow lakes: Lakes Okeechobee and George (Florida, USA) and Lake Taihu (China). Okeechobee and Taihu have been impacted repeatedly by tropical cyclones that have resulted in large amounts of runoff and sediment resuspension, and resultant increases in dissolved nutrients in the water column. In both cases, when turbidity declined, major blooms of the toxic CyanoHAB Microcystis aeruginosa occurred over large areas of the lakes. In Lake George, periods of high rainfall resulted in high dissolved color, reduced irradiance, and increased water turnover rates which suppress blooms, whereas in dry periods with lower water color and water turnover rates there were dense cyanobacteria blooms. We identify a suite of factors which, from our experience, will determine how a particular shallow lake will respond to a future with global warming, flashier rainfall, prolonged droughts and stronger tropical cyclones.
\end{abstract}

Keywords: climate change; shallow lakes; tropical cyclones; sediment-water interactions; harmful cyanobacteria blooms

\section{Introduction}

Global climate change will significantly warm the atmosphere and hydrosphere by the mid-century, resulting in: (a) an increase in extreme precipitation events; (b) an increase in the duration of droughts; and (c) a likely increase in the peak wind velocity during tropical cyclones [1]. These changes are expected to have profound effects on the structure and function of lake ecosystems. Shallow lakes are highly sensitive to these forces, especially lakes occurring in lowland regions of the subtropics and tropics where cyclone activity is high. In shallow lakes, there is strong interaction between the 
sediments and overlying water driven by wind mixing, and these lakes may have alternative equilibria where extreme events can push them from a clear to a turbid state that is resistant to recovery [2]. Shallow eutrophic lakes also may experience CyanoHABs that are stimulated when perturbations liberate nutrients from the sediments and/or when meroplanktonic algae colonies or filaments are carried up into the water column [3,4].

The most-studied effects of climate change on lakes are those related to warming, and the effects are predicted to be substantial. For example, a comparison [5] was made of lakes in Denmark, where winter air temperatures do not drop below $0{ }^{\circ} \mathrm{C}$, with lakes in Canada, where winter air temperatures drop below $-10^{\circ} \mathrm{C}$ and there is winter ice cover on the lakes. The Danish lakes had a four-fold higher ratio of Chlorophyll- $a$ (Chl- $a$ ) to total phosphorus (TP), and a strong relationship between the biomass of zooplankton to phytoplankton that was not observed in the Canadian lakes. Furthermore, comparison of phytoplankton community structure data from lakes along a latitudinal gradient from northern Europe to the tip of South America [6] indicated that percentage dominance of cyanobacteria increases steeply with increasing temperature. Other studies using experimental mesocosms, long-term data analysis, paleoecology and modeling have similarly shown that warming can influence the plankton of shallow lakes [7-9].

A second factor that will affect shallow lakes, the projected increase in intensity of tropical cyclones [10], can only be discerned by evaluating contemporary data from highly-monitored lakes. Much of this research comes from Florida and China, where there are large low-lying shallow lakes in places that are frequently impacted by such storms. In Florida, long-term datasets and modeling have demonstrated that major impacts of tropical storms include: resuspension of lake sediments [11,12]; uprooting and/or inundation of submerged vegetation [13]; and the stimulation of CyanoHABs [14]. Similar responses have been observed in shallow estuaries [15-17]. Recently, evaluation of the effects of tropical cyclones on nutrient and phytoplankton dynamics in Lake Taihu, China [4] has added to this understanding; specifically, how these events affect the occurrence and magnitude of CyanoHABs.

Climate change also may alter the oceanic circulation patterns that influence properties of distant shallow lakes. For example, water column stability and phytoplankton growth are affected by the state of the El Niño Southern Oscillation (ENSO) in Lake Victoria, Africa [18]; the extent of ice cover in the Laurentian Great Lakes is reduced during strong El Niño years [19]; there is deeper warming of lakes in Europe during years with warm phase North Atlantic Oscillation [20]; and the mixing regime of Lake Tahoe in the USA is influenced by the condition of the ENSO [21]. In Lake Okeechobee, Florida, $60 \%$ of the variability in winter rainfall can be explained by the condition of the ENSO [22]. Global warming may substantively alter oceanic climate cycles, increasing their amplitude [23] and therefore their potential to impact lakes. Fewer studies of climate variability have focused on shallow lakes, although Havens et al. [24] recently documented that ENSO-related variation in rainfall, inflow and depth affect both the intensity of summer cyanobacteria blooms and the peak biomass of cladocerans during winter in Lake Harris in central Florida.

Understanding how extreme events and climate variability affect properties of shallow lakes allows us to predict how those ecosystems might be affected by a higher frequency and greater magnitude of such events in a future with a climate that is more variable and extreme. In this study, we use long-term datasets on physical, chemical and biological attributes of two shallow eutrophic cyanobacteria-dominated lakes in Florida (Lakes George and Okeechobee) and a similarly large, cyanobacteria-dominated shallow hypertrophic lake in China (Taihu) to identify effects from: (a) tropical cyclones; and (b) variability in water level, flushing and color associated with changes in rainfall. Using the available data, we develop conclusions and hypotheses about the underlying mechanisms whereby climate change-related changes in extreme events and rainfall/drought could affect shallow subtropical lakes, with a focus on nutrient dynamics and cyanobacteria blooms. 


\section{Materials and Methods}

\subsection{Description of the Study Lakes}

The three lakes (Figure 1) have long-term (15-25 year, monthly to quarterly sampling frequency) datasets of physical, chemical and biological parameters, including Chl- $a$, nitrogen (N) and P concentrations in total and dissolved forms, Secchi disk transparencies, and both phytoplankton and zooplankton species abundances.

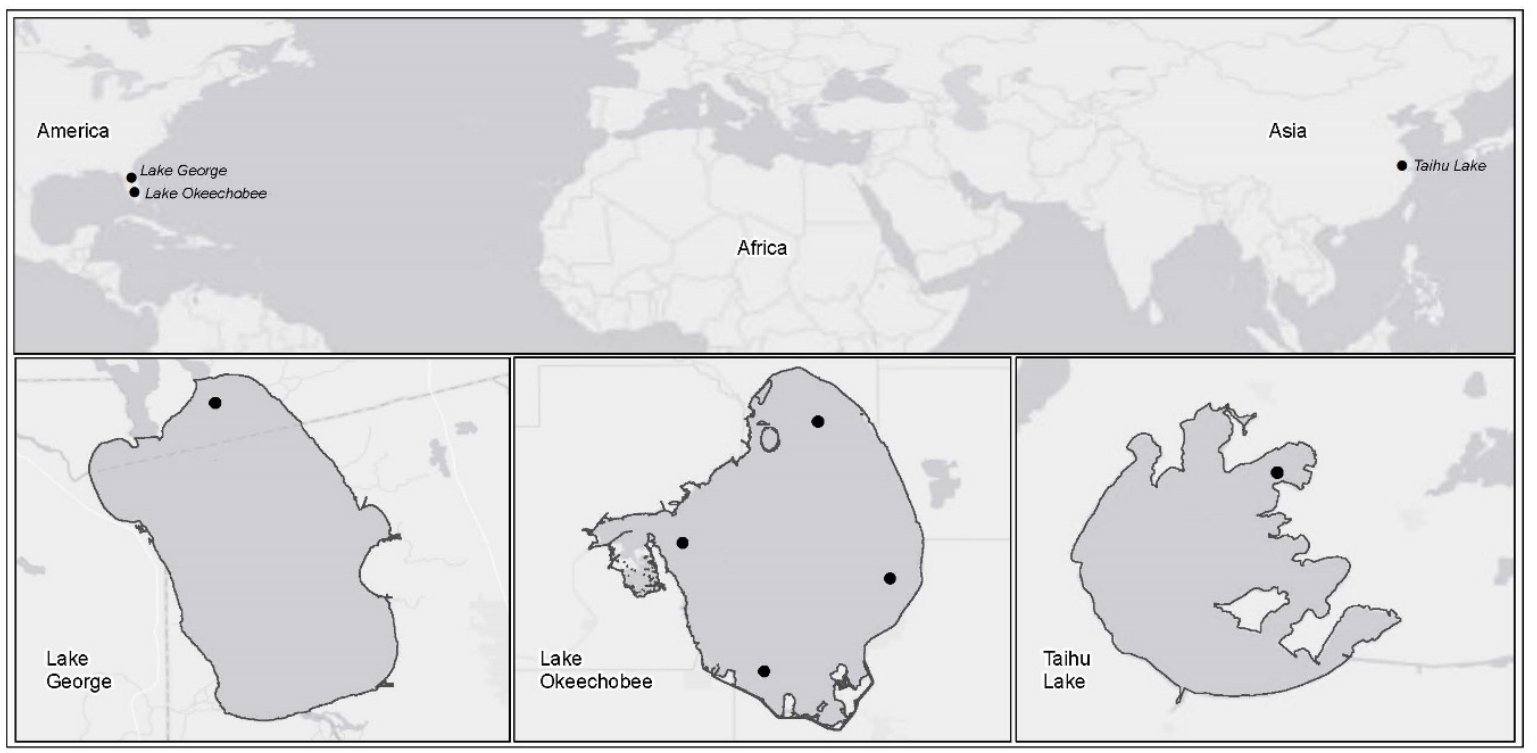

Figure 1. Map of the world showing locations of the three study lakes and inset maps of the lakes and the sampling sites from which data were collected for this study.

Lake Okeechobee $\left(27^{\circ} 00^{\prime} \mathrm{N}, 80^{\circ} 50^{\prime} \mathrm{W}, 1730 \mathrm{~km}^{2}\right.$ surface area, $2.7 \mathrm{~m}$ mean depth) is the largest lake in the southeast United States. It has been impacted repeatedly by tropical cyclones, including three hurricanes (Hurricanes Frances on 5 September 2004, Jeanne on 24 September 2004; and Hurricane Irene on 24 October 2005) during the 15-year period covering the dataset. This lake has distinct zones that differ in their ecological conditions. The pelagic zone is turbid, underlain by flocculent mud sediment, is high in TP, does not support any submerged plants, and phytoplankton production is often limited by light availability [25]. The near-shore zone lies on a higher elevation shelf along the west and south areas of the lake. It has sand and peat sediments, lower turbidity, and can support a large spatial extent of submerged plants when water levels in the lake are relatively low. Phytoplankton production often is limited by $\mathrm{N}$ and sometimes by co-limited by $\mathrm{N}$ and P [26]. The lake's littoral zone is a wetland of emergent plants around the lake's south and west shores, occupying about $500 \mathrm{~km}^{2}$. We examined data from the pelagic and near-shore zones separately, given the major differences in ecological conditions and responses to stressors [12].

Lake George $\left(29^{\circ} 17^{\prime} \mathrm{N}, 81^{\circ} 35^{\prime} \mathrm{W}, 190 \mathrm{~km}^{2}\right.$ surface area, $2.8 \mathrm{~m}$ mean depth) is located in northeast Florida. The lake is a part of the Lower St. Johns River that flows from south to north and empties into the Atlantic Ocean $173 \mathrm{~km}$ downstream near Jacksonville, FL. The lake is located in a shallow-gradient basin, which results in relatively long water residence time and slow water turnover rates (less than 1-6 times per season) [27]. The peak flushing season in the lake is the fall and early winter, during which color levels can be very high (up to 500 platinum-cobalt units, PCU) in high rainfall years [28]. The shallowness of the lake results in polymictic conditions. The lake is eutrophic and regularly experiences blooms of cyanobacteria [27,29]. We examined data taken from one sampling location near the major outlet of this lake into the St. Johns River. 
Lake Taihu $\left(30^{\circ} 56^{\prime}-31^{\circ} 33^{\prime} \mathrm{N}, 119^{\circ} 53^{\prime}-120^{\circ} 36^{\prime} \mathrm{W}, 2338 \mathrm{~km}^{2}\right.$ surface area, $1.9 \mathrm{~m}$ mean depth) is the third largest lake in China. Located $150 \mathrm{~km}$ west of Shanghai and the coast of the East China Sea, Lake Taihu typically experiences tropical cyclones originating in the western Pacific Ocean every summer. There are distinctly different ecological zones in Lake Taihu: phytoplankton-dominated northern and western zones; and macrophyte-dominated eastern and southeastern zones. The open water parts of the lake are hypertrophic and turbid. Prior studies focused on the impacts of tropical cyclones have been conducted near the mouth of Meiliang Bay [4], in the lake's northern zone where cyanobacteria-dominated (Microcystis spp.) blooms have been occurring regularly since the 1980s. Data for evaluating effects of tropical cyclones were taken from that sampling site.

\subsection{Sampling and Laboratory Methods}

\subsubsection{Lake Okeechobee}

Samples were collected at two locations in the pelagic zone and two locations in the near-shore zone from January 2002 to July 2015. At each location, water samples were collected from $50 \mathrm{~cm}$ off the lake bottom to the water surface with a 3-cm diameter PVC tube. Samples were collected for analysis of total suspended solids (TSS), Chl- $a$, ammonium $\left(\mathrm{NH}_{4}\right)$, nitrate and nitrite $\left(\mathrm{NO}_{x}\right)$ and soluble reactive P (SRP). Water samples were analyzed following standard USEPA protocols [30,31], including use of reference standards and blanks. Samples for dissolved nutrients were vacuum-filtered through Whatman GF/F filters ( $0.7 \mu \mathrm{m}$ nominal porosity) before analysis. The total dissolved inorganic $\mathrm{N}$ (DIN) concentration was determined as the sum of $\mathrm{NH}_{4}$ and $\mathrm{NO}_{x}$.

Samples for macro-zooplankton (calanoids, cyclopoids and cladocerans) were obtained by vertical tows of a 30-cm diameter $153 \mu \mathrm{m}$ mesh plankton net. Animals were preserved in $40 \%$ (final concentration) chilled formalin-sucrose solution. Micro-zooplankton (rotifers and nauplii) was sampled with the integrated sampling tube. Approximately $20 \mathrm{~L}$ of that water was placed into a polyethylene carboy. The water was then poured through a $35 \mu \mathrm{m}$ mesh plankton net to collect the micro-zooplankton, which were preserved as above. Phytoplankton was collected in the same manner, and aliquots of whole water $(100 \mathrm{~mL})$ were preserved with Lugol's solution and kept in amber plastic bottles. All microscopic counts were done by enumerating at least 400 individuals in order to achieve a counting accuracy of $90 \%$. Phytoplankton, nauplii and rotifers were counted with the inverted microscope technique [32] after $24 \mathrm{~h}$ of settling. The biovolume of individual phytoplankton cells, including those in filaments and colonies, was determined by measuring dimensions and then calculating the volumes of similarly-shaped geometric solids. Biomass of phytoplankton was

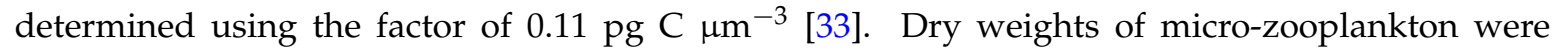
determined from published length-weight relationships and then converted to biomass using a factor of $0.075 \mathrm{pg} \mathrm{C} \mathrm{pg}^{-1}$ wet weight and assuming that wet weight is 10 times dry weight. Aliquots of macrozooplankton samples were counted at $100 \times$ magnification until 400 individuals had been enumerated, and then the entire sample was scanned at a higher magnification for large rare animals. Dry weights were determined and converted to carbon units in the same manner as was done for micro-zooplankton. There are many different ways to calculate carbon biomass of plankton. In this study, we applied widely used conversion factors [34,35] to maximize the comparability of our data.

Submerged aquatic vegetation (SAV) was mapped in late summer each year from 2002 to 2015. The near-shore zone of the lake was divided into $1 \times 1 \mathrm{~km}^{2}$ grid cells that were put into a Trimble Pathfinder GPS. We sampled cells towards the deeper center of the lake at least two cell units beyond any prior observation of submerged plants. During a one-week sampling campaign, we visited the center point of each grid cell by airboat and using a pair of modified oyster-tongs, sampled submerged vegetation and classified the cell as vegetation present or absent. Data also were obtained regarding presence/absence of particular species-those data are not shown here. The data were plotted in GIS (maps are available for every year on the web site of the South Florida Water Management District www.sfwmd.gov). The total spatial extent of SAV in each year was taken as the sum of $1 \mathrm{~km}^{2}$ grid cells 
with presence of plants. This approach was shown to provide a sufficient estimate of SAV coverage to assess long-term trends, when compared to an earlier approach of sampling many more $0.25 \mathrm{~km}^{2}$ cells [13].

\subsubsection{Lake George}

Mean of water levels were retrieved from a USGS station in Silver Glen Springs from October 1995 to December 2010, and were expressed as cm above the NAVD 1998 (National Geodetic Vertical Datum of 1998) reference point. The station has very similar water level to that in Lake George. Monthly average water levels from this station had a significant positive relationship to monthly total precipitation in nearby Crescent City, FL with 2 -month lag $\left(p<0.0001, r^{2}=0.28\right)$. Monthly average river discharge rates were obtained from a USGS monitoring station in Astor, FL, approximately $15 \mathrm{~km}$ upstream from the lake. Physical and chemical data for this study were obtained from the St. Johns River Water Management District.

Water samples for phytoplankton analysis were taken on a monthly basis with a vertical integrating sampler that captured water from the surface to approximately $0.1 \mathrm{~m}$ above the sediment. Water samples were preserved with Lugol's solution and used to quantify phytoplankton abundances and carbon biomass. Phytoplankton was enumerated using the inverted microscope method [32]. The enumerations were done at $400 \times$ to identify and count to a minimum of 100 cells of a single taxon within 30 random grids. A maximum of 100 grids were counted if 100 cells were not counted within the first 30 grids. Whole-bottom counts at $100 \times$ were also done for quantifying larger-sized phytoplankton $(>30 \mu \mathrm{m})$. Biovolume and wet weight of phytoplankton were calculated by assigning combinations of similar geometrical shapes to each phytoplankton taxon and assuming that the densities of phytoplankton were similar to that of water $\left(1 \mathrm{~g} \cdot \mathrm{cm}^{-3}\right)$ [36]. Wet weight estimates were converted to carbon biomass using conversion coefficients of 0.22 for cyanobacteria, 0.16 for chlorophytes and 0.11 for all other phytoplankton, which included diatoms, dinoflagellates, cryptophytes and other minor groups of phytoplankton $[33,37,38]$.

\subsubsection{Lake Taihu}

Monthly sampling for water quality parameters (temperature, conductivity, turbidity, dissolved oxygen, Secchi disk transparency, N, P and Si, and particulate plus soluble N and P) has been conducted for 25 Years. For examining specific effects of tropical cyclones, high-frequency measurements were carried out before, during and after the passage of Typhoons Muifa (from 5 to 9 August 2011) and Haikui (from 6 to 16 August 2012) [4] at the Meiliang Bay site. Lake water at the sediment-water interface was sampled every hour to determine $\mathrm{NH}_{4}$ and SRP concentrations during Typhoon Muifa, and lake water at the surface, middle and bottom layers of the lake water column was sampled twice (6:00 and 18:00) every day to determine TN, TP, $\mathrm{NH}_{4}$ and SRP concentrations; during Typhoon Haikui, lake water was sampled to determine $\mathrm{NH}_{4}, \mathrm{NO}_{x}$ and SRP concentrations every three hours. Wind speed was recorded every 10 or 15 min by a monitoring buoy operated by the Global Lake Ecological Observatory Network (GLEON). Physical-chemical indicators, including water temperature, turbidity, phycocyanin (PC) concentration and dissolved oxygen (DO) saturation in the middle layer of the lake water column were measured every $10 \mathrm{~min}$ with a Yellow Springs Instruments (YSI) 6600 V2 multi-sensor sonde.

Nutrient and Chl- $a$ concentrations in the water of the entire lake are determined every month by the Taihu Laboratory for Lake Ecosystem Research (TLLER). In total, 32 sites are chosen in the lake to make regular observations in February, May, August and November, with 14 sites (observed every month) located in the northern part of the lake, where phytoplankton blooms occurred much more frequently. 


\subsection{Data Analysis}

\subsubsection{Lake Okeechobee}

Fine-scale temporal trends in DIN, SRP, TSS, Chl- $a$, and SAV were examined to observe the dynamics of these attributes following passages of tropical cyclones. We also divided the data into before hurricane (January 2002 to July 2004) and after hurricane (July 2005 to February 2007) periods and compared SRP, DIN, SD and the biomass of zooplankton and phytoplankton between those two periods of time using one-way ANOVA. We also compared the mean daily irradiance in the mixed layer $\left(I_{\mathrm{m}}\right)$ using an established method [39]. $I_{\mathrm{m}}$ is more suitable than SD with respect to light availability for phytoplankton because it takes into account seasonal variations in incident PAR, in addition to attenuation in the water column. For calculating $I_{\mathrm{m}}$, because we did not have data on underwater irradiance, we determined the light attenuation coefficient $\left(K_{t}\right)$ from the relationship SD $=1.7 / K_{t}[40]$ and we assumed that surface PAR followed a seasonal pattern identified by [41] for this lake zone.

\subsubsection{Lake George}

Principal component analysis (PCA) of phytoplankton and hydrological factors in Lake George were performed on a z-scale monthly data from October 1995 to December 2010 by hmisc and vegan packages in $R$ programming 3.0.2 to visualize sample ordinations between cold (October to April) and warm (May-September) months. Student's t-test was performed using JMP ${ }^{\circledR}$ version 11 to compare means between above- and below-average water levels. Annual means between 1996 and 2010 of water chemistry variables and phytoplankton were calculated from monthly means from samples.

\subsubsection{Lake Taihu}

For Lake Taihu, we assessed both short term and long-term effects of typhoons on phytoplankton in the lake. High-frequency data during the passage of two typhoons were analyzed using Microsoft Excel 2010 and SPSS 13.0 software. For the longer term effect study, we noted all the typhoons that passed over Lake Taihu in the last eight years (from 2005 to 2012), and calculated monthly Chl- $a$ amount in the entire lake based on the monthly Chl- $a$ concentration at the 32 sites over the eight years. The entire lake was divided into 32 parts using the Tyson polygon method, and the Chl- $a$ concentration $\left(\mu \mathrm{g} \cdot \mathrm{L}^{-1}\right)$ in each polygon was multiplied with water volume (L) to estimate Chl- $a$ mass $(\mathrm{g})$. The monthly Chl- $a$ mass (metric tons) was the summation of Chl- $a$ mass in each polygon. Cyanobacteria, which accounted for a large fraction of bloom biomass, was assessed by measuring both Chl- $a$ and PC pigment concentrations using a Yellow Springs Instruments (YSI) 6600 V2 multi-sensor sonde [4].

Algal bloom areas in Lake Taihu calculated through satellite imagery were derived from the Moderate Resolution Imaging Spectroradiometer (MODIS) Floating Algal Index [42] and implemented to process MODIS data for Taihu. MODIS Level-0 data were obtained from the National Aeronautics and Space Administration (NASA) [42].

\section{Results}

\subsection{Lake Okeechobee}

The three hurricanes that passed over or near Lake Okeechobee in 2004 and 2005 had major effects on both the pelagic and near-shore zones of the lake (Figure 2). Phytoplankton biomass was reduced by three-fold in both zones; SD transparency and $I_{\mathrm{m}}$ were cut in half; and there was nearly a three-fold increase in the amounts of DIN and SRP in the water column following storm passage. In contrast to the phytoplankton response, zooplankton biomass increased significantly in both lake zones, due almost entirely to a response by one species of copepod, Arctodiaptomus dorsalis, which is the dominant crustacean in the lake. Looking more closely at these changes with the historical time series (Figure 3), one can observe sharp increases in DIN and SRP immediately after the two September 2004 storms, 
a decline in DIN during summer 2005 (while SRP remained high) and then a second spike in DIN following the October 2005 storm.
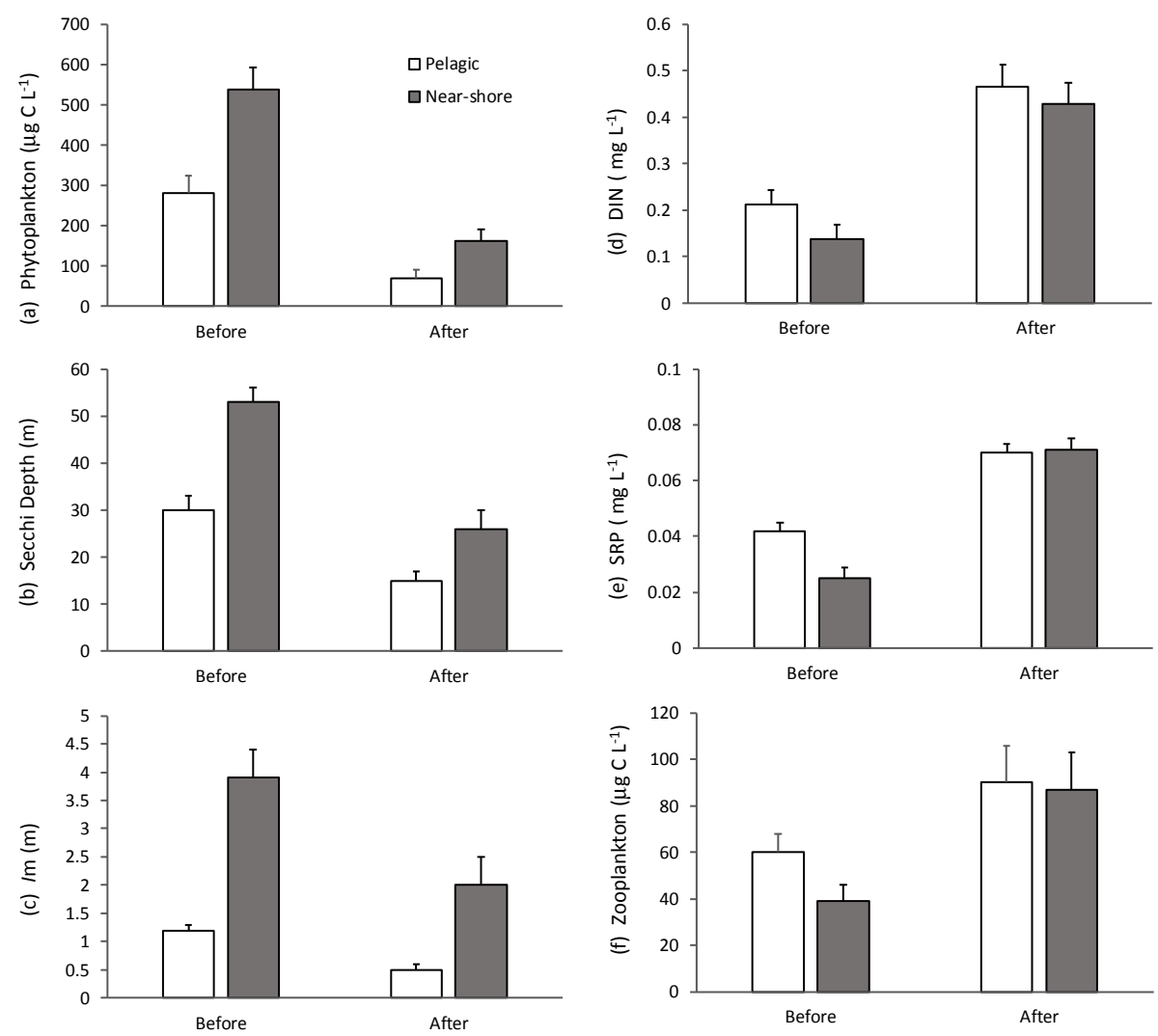

Figure 2. Conditions in Lake Okeechobee before and after the hurricanes of 2004-2005. Data are presented as means with standard error bars. In every case, the differences are statistically significant at $p<0.05$.

(a) Near-Shore

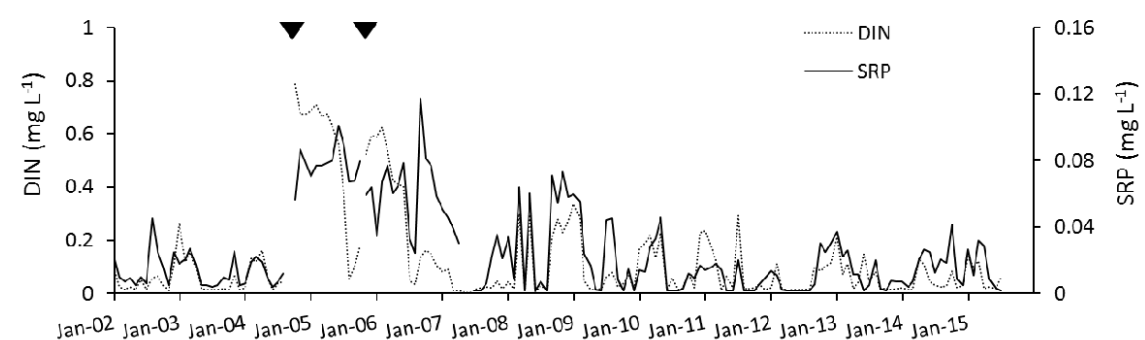

(b) Pelagic

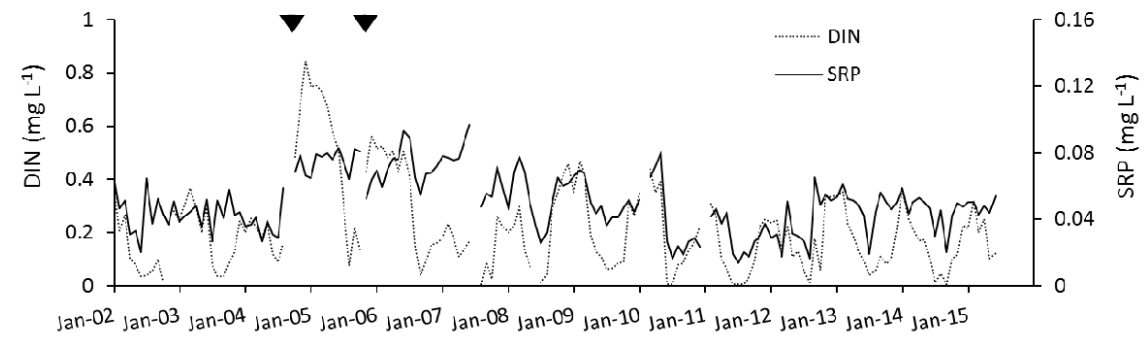

Figure 3. Time series of DIN and SRP concentrations in the near-shore (a) and pelagic zones (b) of Lake Okeechobee, in the context of impacts of two hurricanes in 2004 and one hurricane in 2005. The two hurricanes in 2004 were so close together in time that they are represented by a single triangle indicating the timing. 
The concentration of SRP remained elevated for nearly a year after the hurricanes, especially in the pelagic zone, while DIN more quickly returned to pre-hurricane concentrations. The temporal dynamics of Chl- $a$ and TSS concentrations indicate the important role that light limitation plays in this shallow lake, where there is seasonal resuspension of surface sediments, which was considerably amplified by the hurricanes (Figure 4). After the storms in 2004 and again in 2005, TSS concentrations spiked to high levels in both the near-shore and pelagic zones. Between the two storm periods, in summer 2006, TSS dropped back to a low level and there was a large increase in Chl- $a$, coinciding with the observed reduction of DIN concentrations. This bloom was dominated by the CyanoHAB $M$. aeruginosa, which covered a large portion of the lake, and was also observed in downstream rivers. The bloom was one of the most intense ever observed on the lake, had very high levels of the cyanotoxin microcystin associated with it (SFWMD, unpublished data), but was short-lived because of high levels of suspended inorganic solids and greatly reduced irradiance that were created immediately after the third hurricane (Wilma; 2005). A second bloom did not happen after this particular hurricane, indicating that hurricane effects may not be predicted in a simple manner, at least not in lakes with high inorganic sediment loads to the water column.

(a) Near-Shore

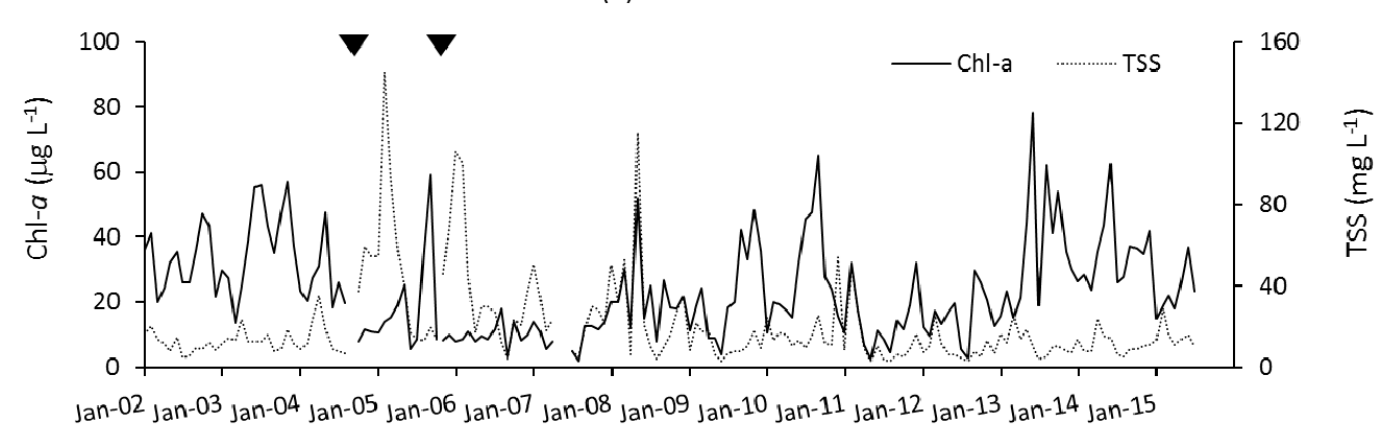

(b) Pelagic

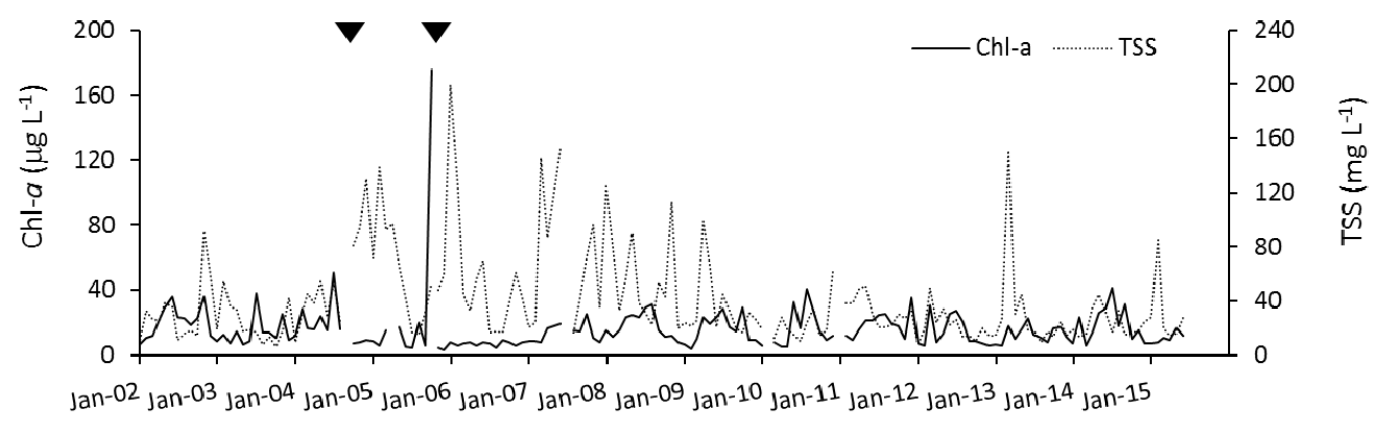

Figure 4. Time series of Chl- $a$ and TSS concentrations in the near-shore and pelagic zones of Lake Okeechobee, in the context of impacts of two hurricanes in 2004 and one hurricane in 2005. The two hurricanes in 2004 were so close together in time that they are represented by a single triangle indicating the timing.

The hurricanes that affected water quality and plankton dynamics in the open water zones of Lake Okeechobee also had a major impact on SAV (Figure 5). In August 2004, just one month before the first two hurricanes impacted the lake, the annual survey indicated a coverage of more than 40,000 hectares of SAV. This was reduced to 8000 hectares from the direct damaging impacts of the first two storms and then to 3000 hectares from the third storm. Yet, in subsequent years, water levels in the lake were sufficiently low and suspended solids declined to a low enough level that SAV quickly regained its coverage, to nearly 30,000 hectares in the year after the last hurricane and then up as high 
as 50,000 hectares by 2009. There have not been land-falling hurricanes in Florida since 2005 and SAV has remained at high levels in the lake.

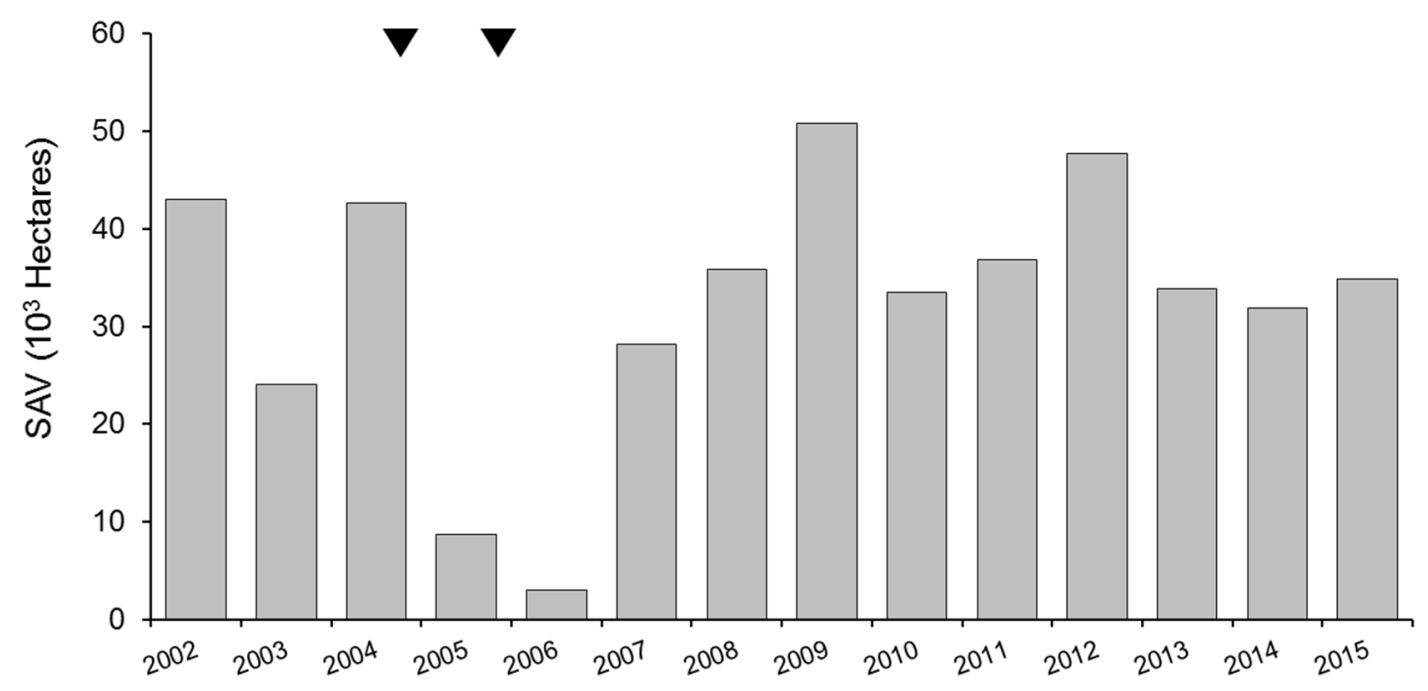

Figure 5. Time series of yearly estimates of the spatial extent of SAV in Lake Okeechobee in the context of three hurricanes that impacted the lake in 2004 and 2005.

\subsection{Lake George}

Time series of daily monthly phytoplankton biomass indicated overall seasonal patterns over the years, with some fluctuations (Figure 6). Cyanobacteria dominated the phytoplankton community in the lake most of the year while other phytoplankton (dominated by diatoms, chlorophytes and euglenophytes) increased in biomass during cold months compared to warmer months. Phytoplankton biomass levels during the warm seasons of 1995, 1998, 2002-2005, and 2009 were relatively low compared to other years in the time-series. The latter years were El Niño periods characterized by above-average rainfall and water levels.

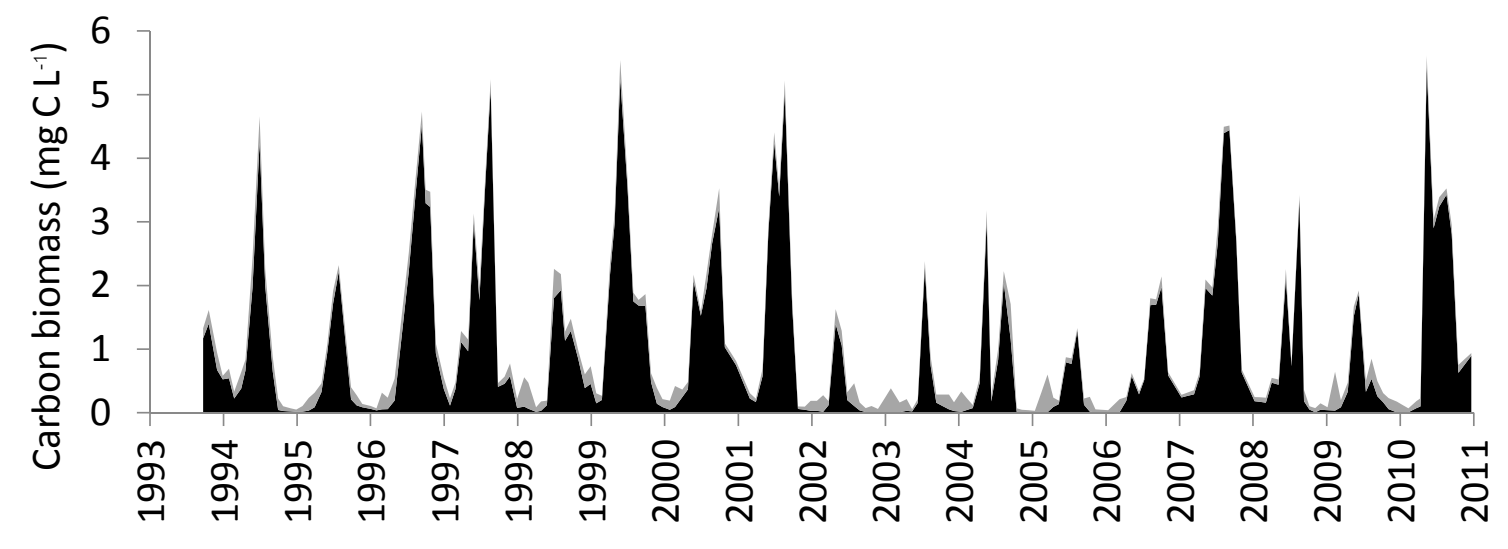

\section{- Cyanobacteria mg Other phytoplankton mg}

Figure 6. Time series of cyanobacteria (black) and all other (grey) phytoplankton carbon biomass in Lake George.

Relationships among groups of phytoplankton and hydrological factors were revealed in PCA ordinations (Figure 7). Cyanobacteria biomass was negatively related to water levels and discharge, while other phytoplankton showed a positive relationship to the two hydrological factors. 


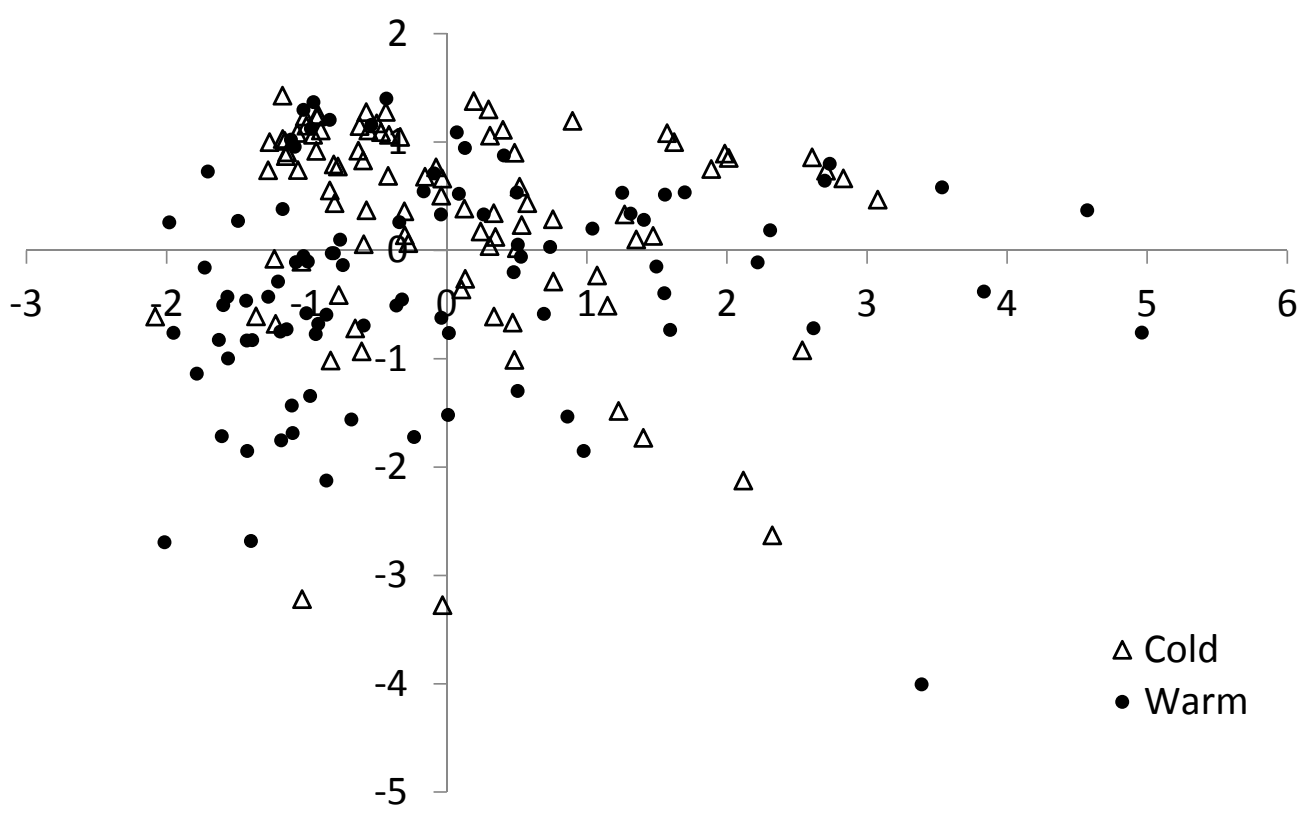

Figure 7. PCA Biplot showing negative relationships between cyanobacteria and water levels and discharge rates while other phytoplankton showed positive relationships to the two hydrological factors.

Trends in phytoplankton biomass and related water chemistry were compared for periods of above-average and below-average water levels (Figure 8). The averaged biomass of cyanobacteria in years with above-average water levels were significantly lower than in years with below-average water levels. Other eukaryotic phytoplankton showed a contrasting trend, with higher averaged monthly biomass in years with higher water levels. In terms of other environmental parameters, average TN concentrations did not differ between periods of high and low water levels, but TP and color (CDOM) were significantly higher during years of high rainfall and elevated water levels.
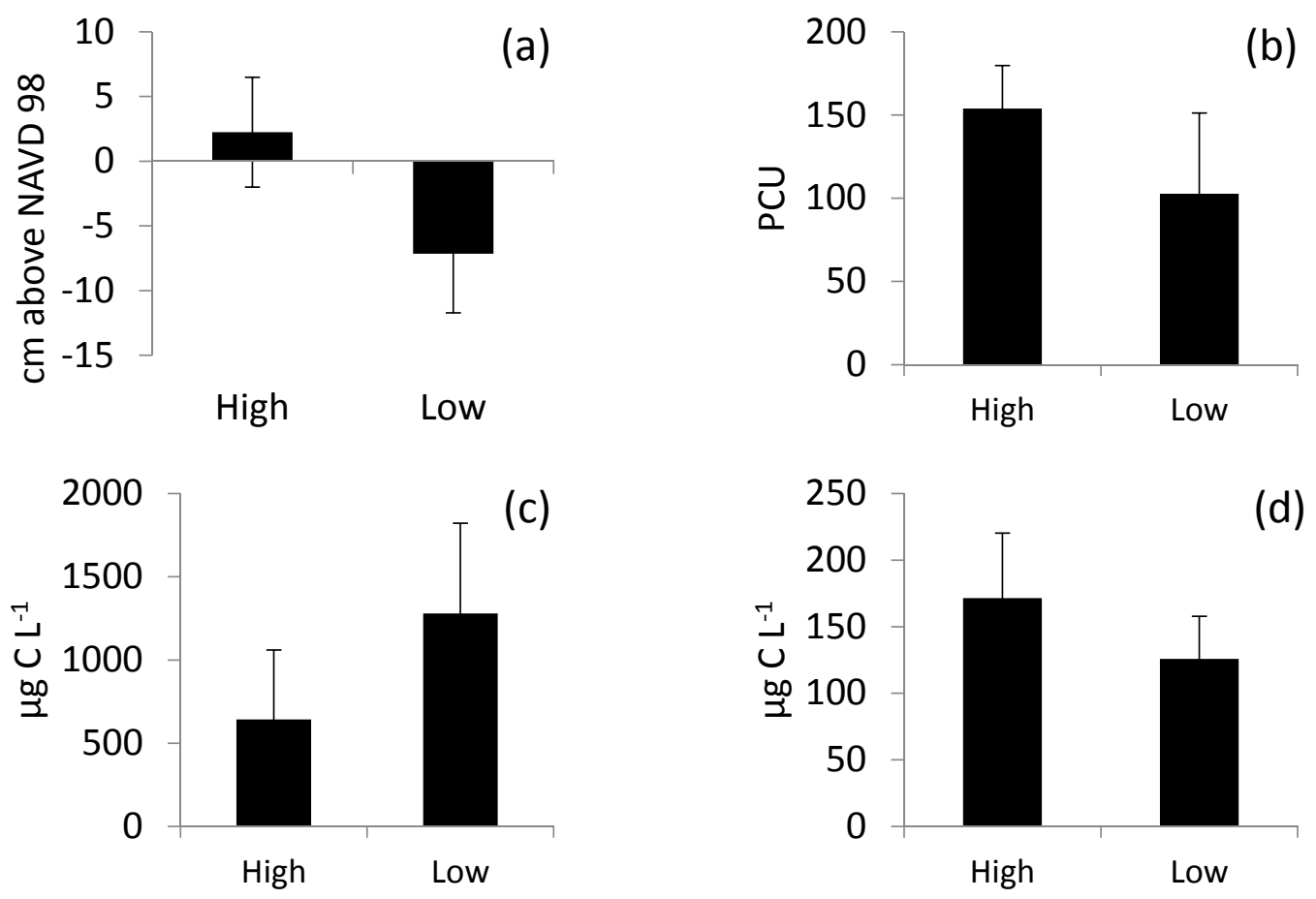

Figure 8. Cont. 

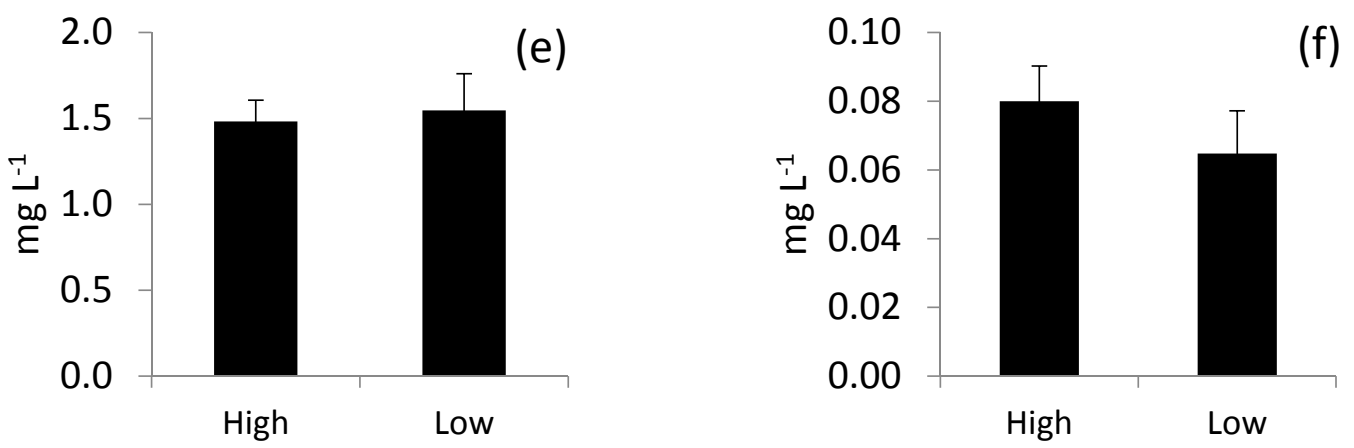

Figure 8. Comparisons of mean values of key parameters between years of above- (i.e., high) and below-average (i.e., low) water level in Lake George from 1996 to 2010. All comparisons are significantly different $(p<0.05)$ except TN. Bars represent one standard deviation.

\subsection{Lake Taihu}

In Lake Taihu, CyanoHABs occurred in most parts of the northwestern and central lake following the passage of both Typhoons Muifa and Haikui, according to satellite imagery [4]. Turbidity increased when the wind speed increased (up to $54 \mathrm{~km} \cdot \mathrm{h}^{-1}$ during Muifa and $68 \mathrm{~km} \cdot \mathrm{h}^{-1}$ during Haikui), and water temperature and PC concentration were well-mixed in the water column during the large wind period. One day after the passage of Typhoon Muifa, wind speed decreased to less than $18 \mathrm{~km} \cdot \mathrm{h}^{-1}$, and dense CyanoHABs accumulated in Meiliang Bay, while temperature and DO exhibited vertical gradients in the stratified water column. The greatest variation of water temperature between the surface and bottom layer of the water column was $3{ }^{\circ} \mathrm{C}$. The phytoplankton blooms were dominated by buoyant $M$. aeruginos a colonies, which accumulated at the water surface under the elevated surface temperature and calm conditions. The peak value of PC concentration at the surface of the lake water during the bloom period was over 200,000 cells $\cdot \mathrm{mL}^{-1}$.

Dissolved inorganic nutrients at the sediment-water interface increased with wind speed. During Typhoon Muifa, $\mathrm{NH}_{4}$ concentrations increased over two times and phosphate increased five times, and both had significant correlation with wind speed. During Typhoon Haikui, $\mathrm{NH}_{4}, \mathrm{NO}_{x}$ and SRP all increased nearly $70 \%$ (Figure 9). When the CyanoHABs occurred following Typhoon Muifa, total $\mathrm{N}$ and $\mathrm{P}$ at the surface water increased strongly and significantly, by $260 \%$ and $300 \%$ respectively, while $\mathrm{NH}_{4}$ and SRP at the sediment-water interface increased markedly, by $50 \%$ and $130 \%$, respectively. Both the large wind events and subsequent bloom events stimulated dissolved nutrient release from sediments, largely due to the disturbance of surface sediments and presence of low oxygen concentrations at the sediment-water interface.

Tropical cyclones also had lasting effects on nutrients and phytoplankton in Lake Taihu, based on the storm passages and monthly in situ water quality data in the lake. Chl- $a$ calculated from 32 sampling sites was comparatively higher in the month following the passage of the storms (Figure 10). Satellite imagery data also indicated that, throughout the lake, the bloom areas were larger at the end of August in 2009, 2011 and 2012, years when typhoons passed over the lake at the beginning of August, in contrast with 2010, in which year no typhoons occurred. 

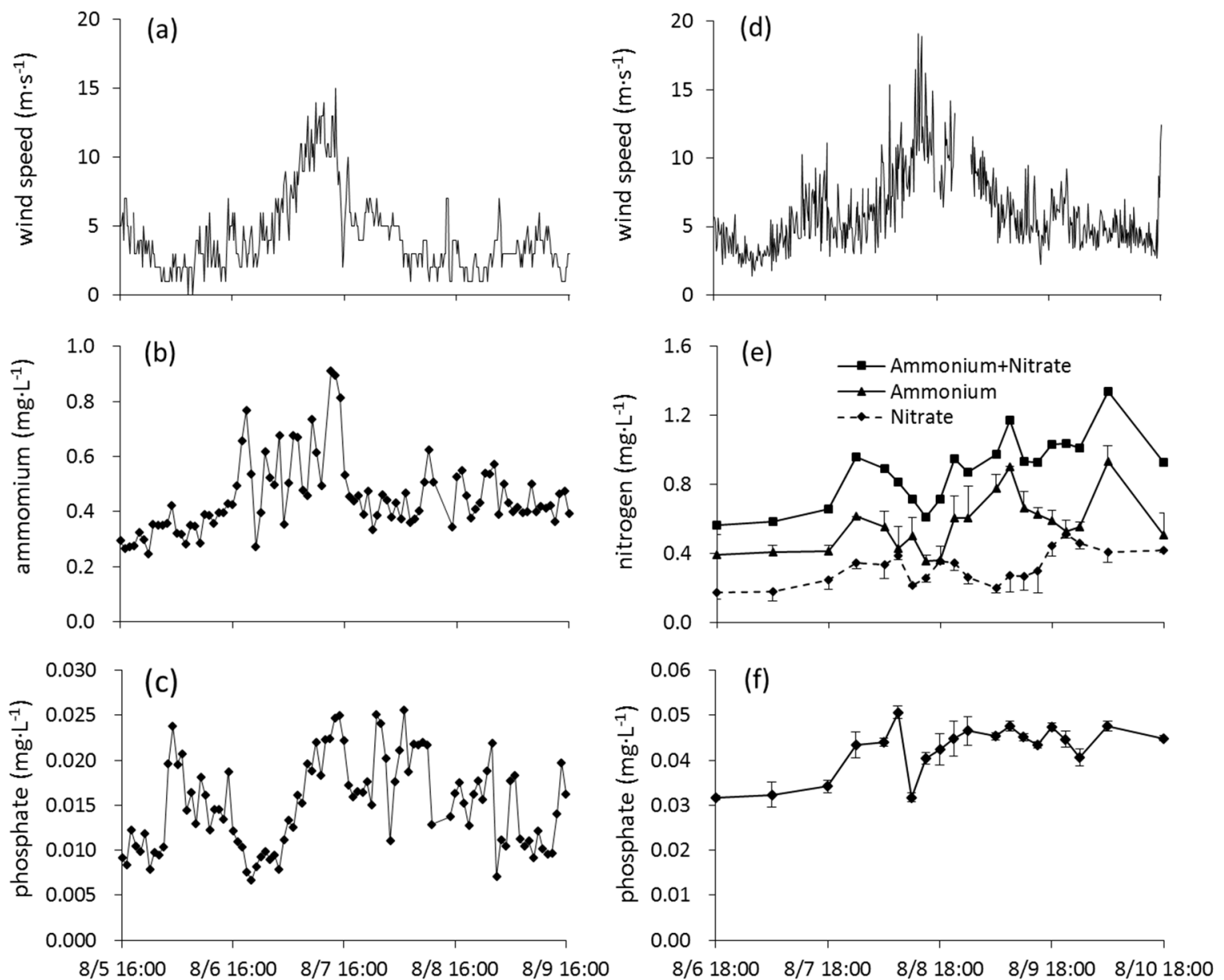

Figure 9. Wind speed $(\mathbf{a}, \mathbf{d})$ and nutrient concentrations $(\mathbf{b}, \mathbf{c}, \mathbf{e}, \mathbf{f})$ at the sediment-water interface at the sampling site in Meilaing Bay, Lake Taihu during Typhoons Muifa $(\mathbf{a}, \mathbf{b}, \mathbf{c})$ and Haikui $(\mathbf{d}, \mathbf{e}, \mathbf{f})$.

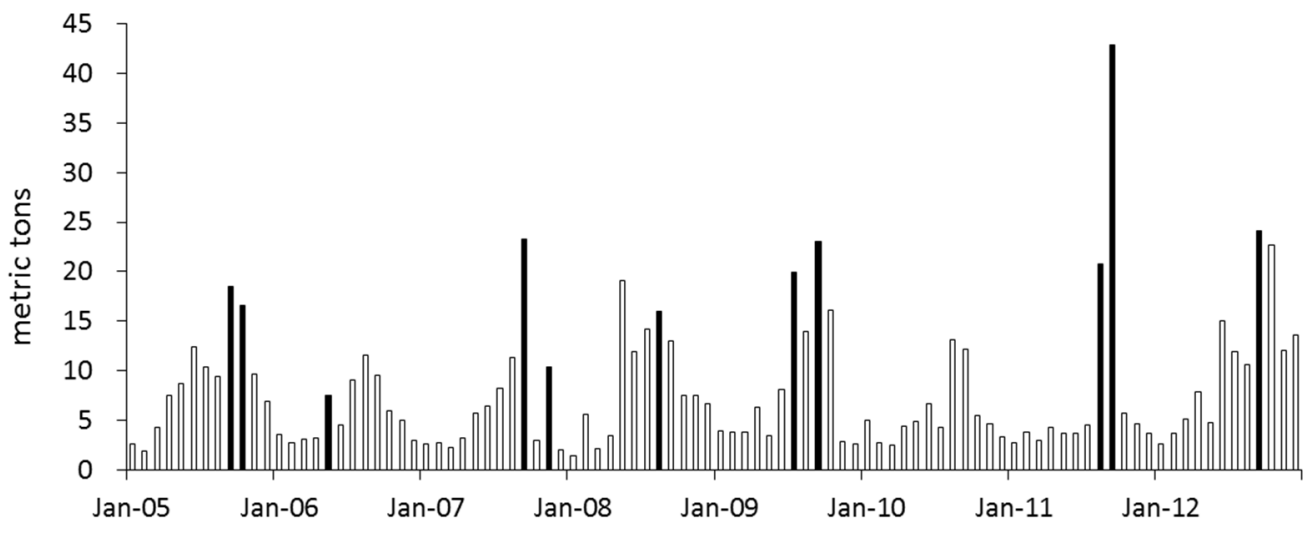

Figure 10. Monthly Chl- $a$ mass in Taihu from 2005 to 2012, based on data from 32 sampling sites. Black columns represent Chl- $a$ mass in the next month after tropical cyclones passed.

\section{Discussion}

Global climate change is expected to result in a variety of environmental changes [1] that will directly affect the structure and function of lake ecosystems. The severity and/or duration of droughts may be enhanced, leading to periods of extreme low water levels [1,10,43]. Rainfall may be concentrated as intense episodic events that could transport high loads of nutrients and solids to lakes, as well as 
resulting in deep water that could directly affect nutrient cycling, light availability and submerged vegetation in shallow lakes [13]. The frequency of occurrence of high intensity tropical cyclones is predicted to increase with a warming atmosphere $[43,44]$ and it is further predicted that there will be an increase in "peak wind intensities" because of ocean warming [1]. As an example, it recently was predicted [45] that incidences of grey swan tropical cyclones, defined as high impact storms that cannot be predicted based on past history, will increase considerably. Such intense and unpredictable storms for Tampa, Florida currently have a probability of occurrence in any given year of 1 in 10,000. By the end the century, the predicted probability drops to 1 in 700 .

Shallow lakes have attributes that make them particularly susceptible to these climate-related changes because there is an intimate connection between the water column and sediments, and in the subtropics these shallow lowland lakes often occur in proximity to coastal areas that experience both tropical storms and high variability in rainfall and runoff. External forcing (wind, drought, or high rainfall) can change sediment-water interactions, and this in turn can affect nutrient recycling, CyanoHABs, submerged vegetation and fisheries [46]. Some nutrient-enriched shallow lakes also have alternative states [47]: a clear state with macrophytes and turbid state with phytoplankton. A major disruption of submerged vegetation due to a hurricane, a drought, or a period of increased water depth could transform a lake to a turbid phytoplankton-dominated state and it may be very difficult for it to return to a clear-water plant-dominated state [48].

The present study provides examples indicating that major changes can occur in water chemistry, light availability, phytoplankton, zooplankton and SAV as a result of both extreme weather events and cyclical changes in water level. In all three lakes, large-scale changes in weather or climate resulted in changes in water chemistry and plankton that were extreme compared to typical seasonal or year-to-year variability that is caused by other environmental factors. The hurricanes that passed over or near Lake Okeechobee had wind velocities at mid-lake of 87,108 and $120 \mathrm{~km} \cdot \mathrm{h}^{-1}$, respectively [12]. The generated large wind seiches and waves collectively uplifted 6-12 cm of mud sediment into the water column [49], which corresponded to 2.1, 0.7 and 1.4 million metric tons of solids in the water [50]. Light limitation resulted in a sharp decline in the biomass of phytoplankton and led to a period of excess DIN and SRP availability in the water column. This led to one of the most intense CyanoHABs ever observed on the lake when solids settled in 2005, and before they were again increased after the third hurricane. At the same time that phytoplankton were reduced as a result of light limitation, crustacean zooplankton increased, perhaps because of reduced predation pressure by sight-feeding fish in the turbid water [12]. After passage of a strong typhoon over Lake Taihu, suspended sediment and nutrient concentrations were greatly increased [4]. Nutrient release from sediments, increased water temperature and thermal stratification immediately after the event resulted in an intense CyanoHAB bloom (M. aeruginosa). It was postulated that, in this shallow lake, algal colonies from the sediments were a direct contributor to the blooms, and that after tropical cyclones, which have occurred 11 times since 2005, blooms occur and then crash, leaving behind an inoculum of cyanobacteria and nutrients at the sediment surface that seeds subsequent cyclone-driven CyanoHABs [4].

If global climate change results in a greater frequency of droughts and more intense hurricanes (that generate more energy and resuspend more sediments), it is reasonable to expect an exacerbation of these stochastic events that will need to be incorporated into long-term lake management plans. This will be particularly important in tropical and subtropical locales on eastern margins of continents in the Northern hemisphere, where lakes are subjected to hurricanes, and in regions of the world where oceanic cycles such as ENSO and their teleconnections to distant wet and dry periods are disrupted.

A critical factor that lake managers will need to quantify for particular lake types is resilience. In the present study, all lakes displayed a high degree of resilience, in that they returned to pre-hurricane or pre-drought conditions within months of the storm events, however, with just a limited number of storms and only three lakes, it is not possible here to quantify the relationship between storm intensity and recovery time. That will require a substantially larger global sampling network with coordinated data collection methods. 
In Okeechobee, the resilience reflected a rather quick settling of suspended material back to the sediment surface, and/or redistribution back towards mid-lake from the near-shore zone, and perhaps the fact that the SAV was not entirely eliminated and, hence, was able to come back quickly and help to prevent algal blooms in the near-shore area. CyanoHABs are also short-lived in Lake Taihu following tropical cyclones, and it is postulated that this occurs because of rapid uptake and depletion of available nutrients from the water column [4].

There are other examples where similar environmental drivers have brought about long-term changes. Lake Annie, a relatively deep lake in Florida, had historically been a clear-water lake, since data were collected starting in 1983, although in more recent years it had been displaying a decline in transparency [51]. Between 1993 and 2005, there were multiple years of high rainfall and a large input of dissolved organic $\mathrm{C}$ into the lake. The lake switched and became a dark water lake and has only slowly recovered its transparency. Lake Apopka, Florida was by a variety of indicators a clear-water lake with vast coverage of SAV until 1946, when a hurricane tore up the SAV and pushed the lake into a phytoplankton-dominated condition that persists today [48]. What sets Lake Apopka apart from Okeechobee are two factors: (1) Okeechobee sediments contain a large percentage of inorganic solids that result in extreme light-limitation when they are suspended into the water column, preventing CyanoHABs from occurring or persisting; and (2) available information suggests that, in Apopka, all of the SAV was torn up and pulverized into particulate organic $C$ and nutrients that fueled algal growth lake-wide. In Okeechobee, the SAV was not totally lost, and its spatial extent is only up to $25 \%$ of the lake surface.

Lake George is another large shallow eutrophic lake in Florida that is subject to intense CyanoHABs, particularly during the warmer months of the year (i.e., May-October) [27]. However, in contrast with Lake Okeechobee, the most intense blooms have occurred during years of below average rainfall and lower water levels [52]. In part, this pattern is attributable to the flow-through character of the lake, which has a major river inflow at the southern end (i.e., upper St. Johns River) and discharge into the lower St. Johns River at the northern end of the lake. The flow-through regime results in overall shorter water turnover rates in Lake George than Lake Okeechobee, and larger differences in water turnover rates between high rainfall/high discharge periods versus low rainfall/low discharge periods [27]. Low discharge and water turnover rates in Lake George during lower than average rainfall periods increase the potential for the buildup of phytoplankton biomass in several ways [52]. The most direct effect relates to the need for sufficient time for relatively slow-growing filamentous (e.g., Anabaena flos-aquae, Planktothrix spp.) and colonial cyanobacteria (e.g., M. aeruginosa) to reach bloom levels of biomass. This relationship is supported by the observation that periods of above average rainfall or strong tropical storm activity (i.e., 1995, 1998, 2002-2005, 2009) exhibited relatively low bloom intensities during the warm seasons, compared to years when rainfall levels were lower.

A secondary issue related to the effects of water turnover rates is the propensity of Lake George to exhibit $\mathrm{N}$ limitation of phytoplankton growth $[53,54]$. The recurring presence of $\mathrm{N}$-limited conditions in the lake is reflected in the strong presence of $\mathrm{N}_{2}$-fixing cyanobacteria in the lake $[27,55]$. Recent estimates of the $\mathrm{N}$ budget and $\mathrm{N}_{2}$ fixation rates for Lake George suggest that $\mathrm{N}_{2}$ fixation contributes over $50 \%$ of external loads of $\mathrm{N}$ to the lake [54]. It is therefore likely that $\mathrm{N}_{2}$ fixation plays a major role in supporting phytoplankton blooms, both directly (i.e., biomass of $\mathrm{N}_{2}$-fixing cyanobacteria) and indirectly through re-cycling of fixed N. Periods of below average rainfall and low water turnover rates likely enhance the latter processes by providing additional time for non-fixing cyanobacteria to take advantage of re-cycled $\mathrm{N}$.

In evaluating the degree to which climate change may affect the long-term management or restoration plans for a shallow lake, resource managers might address a number of questions, which loosely follow a hierarchy [46] to determine the management strategies that shallow lakes might best respond. Here, we have raised similar questions in terms of more extreme weather events and more variable climate cycles, within the context of the observations of the three ecosystems included in this 
study. Because of the small sample size, both in terms of number of lakes and number of storm events, the points made here are necessarily general.

1. Is the lake located in a region that experiences tropical cyclones? If yes, this increases the risk of highly disruptive impacts from cyclones that likely will be exacerbated in a future with cyclones of greater intensity due to global warming. The data presented here indicate that all of the lakes are resilient to the effects of tropical cyclones and recover on time scales of months. But what if in the future those storms are more intense or they follow one-another in close sequence? That could lead to a situation where there is insufficient time for the system to recover before being hit by another storm (Figure 11).

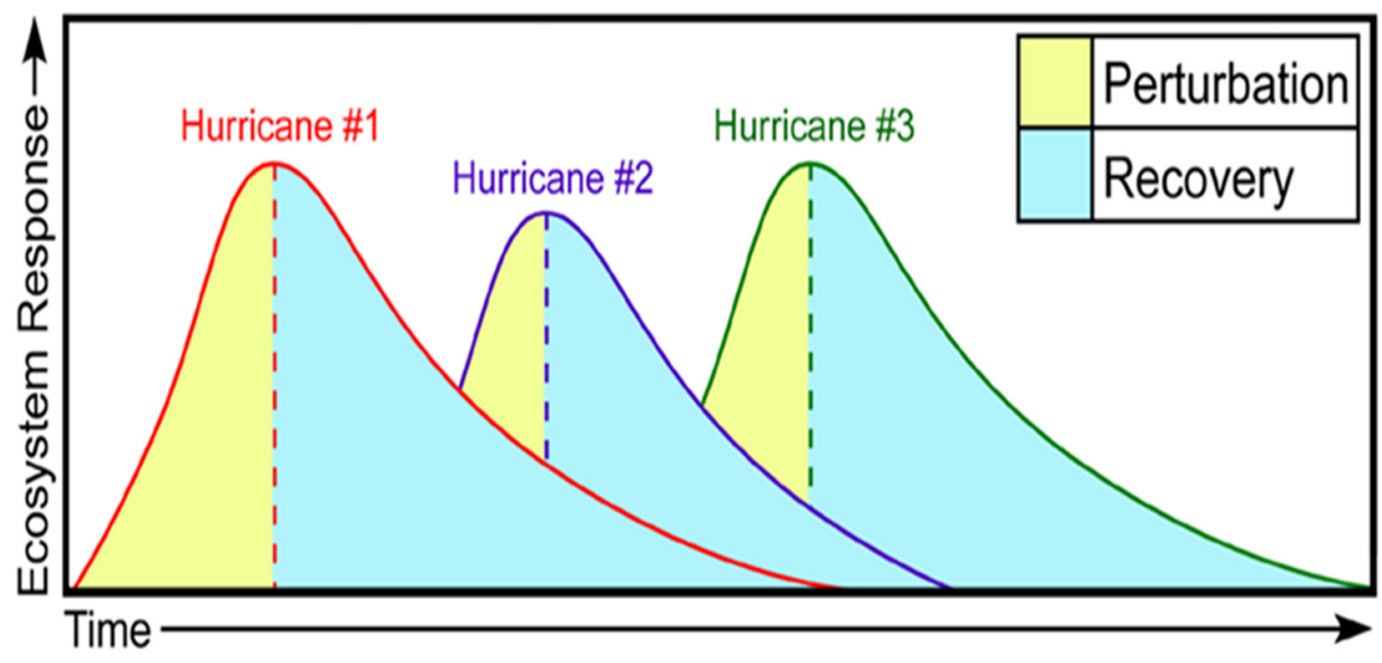

Figure 11. Conceptual diagram illustrating recovery of shallow lakes from hurricanes relative to the frequency of recurrence of events.

2. Is the lake located in a region where oceanic cycles and their teleconnections result in year-to-year or decadal variation in rainfall, which applies to both Lakes Okeechobee and George? If yes, and those ocean cycles are changed as a result of climate change [23], it could markedly alter the dynamics of the lake ecosystems and their long-term response to management actions.

3. Does the lake have a high dynamic ratio, which indicates a large surface area relative to mean depth, which characterize all three lakes in this study? If yes, then for a given amount of wind action on the water surface, a greater amount of energy will shear the sediments, making these lakes more prone to disruption by wind events.

4. Do the sediments contain a high proportion of inorganic solids? If yes, these lakes may recover more quickly because those inorganic solids will block light, limiting phytoplankton development while also not supporting bacterial growth. This appears to be what happened in Lake Okeechobee, especially after the impact of a third hurricane.

5. Are concentrations of TP and TN high in the sediments? If yes, then there is a source of nutrients that can be carried into the water column to stimulate algal and bacterial production. This occurred in Lake Taihu, where dissolved nutrients were released from the sediments into the overlying water during the strong wind period, followed by a bloom period. It also occurred in Lake Okeechobee, and it likely is what stimulated the long-term dominance of cyanobacteria blooms in Lake Apopka, Florida [48].

6. Are cyanobacteria, including bloom-forming species, dominant, as observed in all three lakes in this study? If yes, then it is more likely, considering the factors listed above, that extreme events or changes in water depth and global temperature might stimulate CyanoHABs. Here, we have considered the effects of global climate change on the management of shallow lakes 
only from the perspective of wind and flushing events. There also is evidence that, in a warmer future, cyanobacteria will be favored over other algae in lakes based on optimal growth rates at elevated temperatures and stronger vertical stratification [56] and that lakes with high TP and TN concentrations that undergo warming could experience a non-linear and unpredictable rise in bloom frequency [6]. When combined with the above-mentioned factors, it may render some lakes beyond the reach of any currently available rehabilitation methods, and it supports the view that nutrient reduction is critical now, rather than later when these various effects of global climate change amplify nutrient effects $[57,58]$.

Acknowledgments: The authors are grateful to the South Florida and St. Johns River Water Management Districts for providing long-term data on physical, chemical and biological properties of the two lakes considered in this project. Additional support was provided by the National Natural Science Foundation of China (41501532 and 41230744), International Scientific Cooperation Project (2015DFG91980), the US National Science Foundation Projects (1240851 and 1230543), and the Chinese Ministry of Science and Technology (MOST) International Cooperation Project 2015DFG91980.

Author Contributions: Karl Havens developed the initial and final versions of this manuscript and analyzed the data. John Beaver contributed his expertise and insights by conducting all of the analysis of plankton samples collected in the long-term projects on Lake Okeechobee, and by supporting the writing of the final manuscript. Ed Phlips, Mengyuan Zhu, Akeapot Srifa and Hans Paerl contributed their expertise and insights by supporting the writing of the final manuscript.

Conflicts of Interest: The authors declare no conflicts of interest.

\section{References}

1. Contribution of Working Groups I, II and III to the Fifth Assessment Report of the Intergovernmental Panel on Climate Change; Stocker, T.F., Ed.; Cambridge University Press: Cambridge, UK, 2014.

2. Scheffer, M.; Carpenter, S.; Foley, J.A.; Folke, C.; Walker, B. Catastrophic shifts in ecosystem structure. Nature 2011, 413, 591-596. [CrossRef] [PubMed]

3. Paerl, H.W. Nuisance phytoplankton blooms in coastal, estuarine, and inland waters. Limnol. Oceanogr. 1988, 33, 823-847. [CrossRef]

4. Zhu, M.; Paerl, H.W.; Zhu, G.; Wu, T.; Li, W.; Shi, K.; Zhao, L.; Zhang, Y.; Qin, B.; Caruso, A.M. The role of tropical cyclones in stimulating Cyanobacteria (Microcystis spp.) blooms in hypertrophic Lake Taihu, China. Harmful Algae 2014, 39, 310-321. [CrossRef]

5. Jackson, L.J.; Lauridsen, T.L.; Søndergaard, M.; Jeppesen, E. A comparison of shallow Danish and Canadian lakes and implications for climate change. Freshw. Biol. 2007, 52, 1782-1792. [CrossRef]

6. Kosten, S.; Huszar, V.L.M.; Bécares, E.; Costa, L.S.; Van Donk, E.; Hansson, L.A.; Jeppesen, E.; Kruk, C.; Lacerot, G.; Mazzeo, N.; et al. Warmer climate boosts cyanobacterial dominance in shallow lakes. Glob. Chang. Biol. 2012, 18, 118-126. [CrossRef]

7. Moss, B.; Stephen, D.; Balayla, D.M.; Bécares, E.; Collings, S.E.; Frenández-Aláez, C.; Frenández-Aláez, M.; Ferriol, C.; García, P.; Gomá, J.; et al. Continental-scale patterns of nutrient and fish effects on shallow lakes; synthesis of a pan-European mesocosm experiment. Freshw. Biol. 2004, 49, 1633-1649. [CrossRef]

8. Jeppesen, E.; Meerhoff, M.; Davidson, T.A.; Trolle, D.; Søndergaard, M.; Lauridsen, T.L.; Beklioğlu, M.; Brucet, S.; Bolta, P.; González-Bergonzoni, I.; et al. Climate change impacts on lakes: An integrated ecological perspective based on a multi-faceted approach, with special focus on shallow lakes. J. Limnol. 2014, 73, 84-107. [CrossRef]

9. Shurin, J.B.; Clasen, J.L.; Hamish, S.G.; Pavel, K.; Thompson, P.L. Warming shifts top-down and bottom-up control of pond food web structure and function. Phil. Trans. R. Soc. B 2012, 367, 3008-3017. [CrossRef] [PubMed]

10. Emanuel, K. Increasing destructiveness of tropical cyclones over the past 30 years. Nature 2005, 436, 686-688. [CrossRef] [PubMed]

11. Jin, K.R.; Ji, Z.G. Calibration and verification of a spectral wind-wave model for Lake Okeechobee. Ocean Eng. 2001, 28, 571-584. [CrossRef]

12. Havens, K.E.; Beaver, J.R.; Casamatta, D.; East, T.; James, R.T.; McCormick, P.; Phlips, E.J.; Rodusky, A.J. Hurricane effects on the planktonic food web of a large subtropical lake. J. Plankton Res. 2011, 33, 1081-1094. [CrossRef] 
13. Havens, K.E.; Jin, K.R.; Rodusky, A.J.; Sharfstein, B.; Brady, M.A.; East, T.L.; Iricanin, N.; James, R.T.; Harwell, M.C.; Steinman, A.D. Hurricane effects on a shallow lake ecosystem and its response to a controlled manipulation of water level. Sci. World 2001, 1, 44-70. [CrossRef] [PubMed]

14. Beaver, J.R.; Casamatta, D.A.; East, T.L.; Havens, K.E.; Rodusky, A.J.; James, R.T.; Tausz, C.E.; Buccier, K.M. Extreme weather events influence the phytoplankton community structure in a large lowland subtropical lake (Lake Okeechobee, Florida, USA). Hydrobiologia 2013, 709, 213-226. [CrossRef]

15. Paerl, H.W.; Christian, R.R.; Bales, J.D.; Peierls, B.L.; Hall, N.S.; Joyner, A.R.; Riggs, S.R. Assessing the response of the Pamlico Sound, North Carolina, USA to human and climatic disturbances: Management implications. In Critical Habitats of Environmental Change; Kennish, M., Paerl, H., Eds.; CRC Press: Boca Raton, FL, USA, 2010; pp. 17-42.

16. Hall, N.S.; Paerl, H.W.; Peierls, B.L.; Whipple, A.C.; Rossignol, K.L. Effects of climatic variability on phytoplankton biomass and community structure in the eutrophic, microtidal, New River Estuary, North Carolina, USA. Est. Coast. Shelf Sci. 2013, 117, 70-82. [CrossRef]

17. Paerl, H.W.; Hall, N.S.; Peierls, B.L.; Rossignol, K.L.; Joyner, A.R. Hydrologic variability and its control of phytoplankton community structure and function in two shallow, coastal, lagoonal ecosystems: The Neuse and New River Estuaries, North Carolina, USA. Estuaries Coasts 2014, 37, 31-45. [CrossRef]

18. Cózar, A.; Bruno, M.; Bergamino, N.; Ubeda, B.; Bracchini, L.; Dattilo, A.M.; Loiselle, S.A. Basin-scale control on the phytoplankton biomass in Lake Victoria, Africa. PLoS ONE 2012, 7, e29962. [CrossRef] [PubMed]

19. Van Cleave, K.; Lenters, J.D.; Wang, J.; Verhamme, E.M. A regime shift in Lake Superior ice cover, evaporation, and water temperature following the warm El Niño winter of 1997-1998. Limnol. Oceanogr. 2014, 59, 1889-1898. [CrossRef]

20. Dokulil, M.T.; Jagsch, A.; George, G.D.; Anneville, O.; Jankowski, T.; Wahl, B.; Blenckner, T.; Teubner, K. Twenty years of spatially coherent deepwater warming in lakes across Europe related to the North Atlantic Oscillation. Limnol. Oceanogr. 2006, 51, 2787-2793. [CrossRef]

21. Paerl, H.W.; Richards, R.C.; Leonard, R.L.; Goldman, C.R. Seasonal nitrate cycling as evidence for complete vertical mixing in Lake Tahoe, California-Nevada. Limnol. Oceanogr. 1975, 20, 1-8. [CrossRef]

22. Abtew, W.; Trimble, P. El Niño-Southern Oscillation link to south Florida hydrology and water management applications. Water Resour. Manag. 2010, 24, 4255-4271. [CrossRef]

23. Cai, W.; Santoso, A.; Wang, G.; Yeh, S.W.; An, S.; Cobb, K.M.; Collins, M.; Guilyardi, E.; Lengaigne, M. ENSO and greenhouse warming. Nat. Clim. Chang. 2015, 5, 849-859. [CrossRef]

24. Havens, K.E.; Fulton, R.S.; Beaver, J.R.; Samples, E.E.; Colee, J. Effects of climate variability on cladoceran zooplankton and cyanobacteria in a shallow subtropical lake. J. Plankton Res. 2016. [CrossRef]

25. Phlips, E.J.; Aldridge, F.J.; Hansen, P.; Zimba, P.V.; Ihnat, J.; Conroy, M.; Ritter, R.R. Spatial and temporal variability of trophic state parameters in a shallow subtropical lake (Lake Okeechobee, Florida, USA). Arch. Hydrobiol. 1993, 128, 437-458.

26. Aldridge, F.J.; Phlips, E.J.; Schelske, C.L. The use of nutrient enrichment bioassays to test for spatial and temporal distribution of limiting factors affecting phytoplankton dynamics in Lake Okeechobee, Florida. Arch. Hydrobiol. Adv. Limnol. 1995, 45, 177-190.

27. Phlips, E.J.; Hendrickson, J.; Quinlan, E.; Cichra, M. Meteorological influences on algal bloom potential in a nutrient-rich blackwater river. Freshw. Biol. 2007, 52, 2141-2155. [CrossRef]

28. Phlips, E.J.; Cichra, M.; Aldridge, F.J.; Jembeck, J.; Hendrickson, J.; Brody, R. Light availability and variations in phytoplankton standing crops in a nutrient-rich blackwater river. Limnol. Oceanogr. 2000, 45, 916-929. [CrossRef]

29. Hendrickson, J.; Lowe, E.F.; Dobberfuhl, D.; Sucsy, P.; Campbell, D. Characteristics of Accelerated Eutrophication in the Lower St. Johns River Estuary and Recommended Targets to Achieve Water Quality Goals for the Fulfillment of TMDL and PLRG Objectives; St. Johns River Water Management District: Palatka, FL, USA, 2003.

30. Methods for Chemical Analysis of Water and Waste Water; United States Environmental Protection Agency: Washington, DC, USA, 1979.

31. South Florida Water Management District Field Sampling Manual; SFWMD: West Palm Beach, FL, USA, 2008.

32. Lund, J.G.W.; Kipling, C.; LeCren, E.D. The inverted microscope method of estimating algal numbers and the statistical basis of estimates by counting. Hydrobiologia 1958, 11, 143-170. [CrossRef]

33. Rocha, O.; Duncan, A. The relationship between cell carbon and cell-volume in fresh-water algal species used in zooplanktonic studies. J. Plankton Res. 1985, 7, 279-294. [CrossRef] 
34. Auer, B.; Elzer, U.; Arndt, H. Comparison of pelagic food webs in lakes along a trophic gradient and with seasonal aspects: Influence of resource and predation. J. Plankton Res. 2004, 26, 697-709. [CrossRef]

35. Havens, K.E.; Beaver, J.R.; East, T.L. Plankton biomass partitioning in a eutrophic subtropical lake: Comparison with results from temperate lake ecosystems. J. Plankton Res. 2007, 18, 1605-1625. [CrossRef]

36. Edler, L. Recommendations on Methods for Marine Biological Studies in the Baltic Sea: Phytoplankton and Chlorophyll; The Baltic Marine Biologists: Stockholm, Sweden, 1979.

37. Lundgren, A. Experimental lake fertilization in the Kuokkel Area, northern Sweden: Changes in sestonic carbon and the role of phytoplankton. Int. Ver. Theor. Ang. Limnol. Verh. 1978, 20, 863-868.

38. Ahlgren, G. Comparison of methods for estimation of phytoplankton carbon. Arch. Hydrobiol. 1983, 98, 489-508.

39. Stefan, H.; Skoglund, T.; Megard, R.O. Wind control of algal growth in eutrophic lakes. J. Environ. Eng. Div. ASCE 1976, 102, 1201-1203.

40. Wetzel, R.G. Limnology; Academic Press: New York, NY, USA, 2001.

41. Oswald, W.J.; Gataas, H.B. Phytosynthesis in sewage treatment. Trans. Am. Soc. Civ. Eng. 1957, 122, 73-97.

42. Hu, C.M. A novel ocean color index to detect floating algae in the global oceans. Remote Sens. Environ. 2009, 113, 2118-2129. [CrossRef]

43. Webster, P.J.; Holland, G.J.; Curry, J.A.; Chang, H.R. Changes in tropical cyclone number, duration, and intensity in a warming environment. Science 2005, 309, 1844-1846. [CrossRef] [PubMed]

44. Elsner, J.B.; Kossin, J.P.; Jagger, T.H. The increasing intensity of the strongest tropical cyclones. Nature 2008, 455, 92-95. [CrossRef] [PubMed]

45. Lin, B.; Emanuel, K. Grey swan tropical cyclones. Nat. Clim. Chang. 2016, 6, 106-111. [CrossRef]

46. Moss, B.; Madgwick, J.; Phillips, G. A Guide to the Restoration of Nutrient-Enriched Shallow Lakes; W.W. Hawes, Inc.: London, UK, 1996.

47. Scheffer, M. Alternative stable stages in eutrophic shallow freshwater systems: A minimal model. Hydrobiol. Bull. 1989, 23, 73-83. [CrossRef]

48. Bachmann, R.W.; Hoyer, M.V.; Vinzon, S.B.; Canfield, D.E. The origin of the fluid mud layer in Lake Apopka, Florida. Limnol. Oceanogr. 2005, 50, 629-635. [CrossRef]

49. James, R.T.; Chimney, M.J.; Sharfstein, B. Hurricane effects on a shallow lake ecosystem, Lake Okeechobee, Florida (USA). Arch. Hydrobiol. 2005, 163, 225-239. [CrossRef]

50. Abtew, W.; Iricanin, N. Hurricane effects on south Florida water management system: A case study of Hurricane Wilma of October 2005. J. Spat. Hydrol. 2008, 8, 2-20.

51. Gaiser, E.E.; Deyrup, N.D.; Bachmann, R.W.; Battoe, L.E.; Swain, H.M. Effects of climate variability on transparency and thermal structure in subtropical, monomictic Lake Annie, Florida. Arch. Hydrobiol. 2009, 175, 217-230. [CrossRef]

52. Srifa, A.; Phlips, E.J.; Cichra, M.F.; Hendrickson, J.C. Phytoplankton dynamics in a subtropical lake dominated by cyanobacteria: Cyanobacteria like it hot and sometimes dry. Aquat. Ecol. 2016. [CrossRef]

53. Piehler, M.F.; Dyble, J.; Moisander, P.H.; Chapman, A.D.; Hendrickson, J.; Paerl, H.W. Interactions between nitrogen dynamics and the phytoplankton community in Lake George, Florida, USA. Lake Reserv. Manag. 2009, 25, 1-14. [CrossRef]

54. Doron, M. Aquatic Nitrogen Fixation Patterns, Rates and Controls in a Shallow, Subtropical Lake. Master' Thesis, University of Florida, Gainesville, FL, USA, 2010.

55. Dong, L. Factors Controlling Phytoplankton Community and Dynamics during Cyanobacterial Bloom. Master's Thesis, University of Florida, Gainesville, FL, USA, 2010.

56. Paerl, H.W.; Huisman, J. Climate change: A catalyst for global expansion of harmful cyanobacterial blooms. Environ. Microbiol. Rep. 2009, 1, 27-37. [CrossRef] [PubMed]

57. Moss, B.; Kosten, S.; Meerhoff, M.; Battarbee, R.W.; Jeppesen, E.; Mazzeo, N.; Havens, K.; Lacerot, G.; Liu, Z.; De Meester, L.; et al. Allied attack: Climate change and eutrophication. Inland Waters 2011, 1, 101-105. [CrossRef]

58. Havens, K.E.; Paerl, H.W. Climate change at a crossroad for control of harmful algal blooms. Environ. Sci. Technol. 2015, 49, 12605-12606. [CrossRef] [PubMed]

(C) 2016 by the authors; licensee MDPI, Basel, Switzerland. This article is an open access article distributed under the terms and conditions of the Creative Commons Attribution (CC-BY) license (http://creativecommons.org/licenses/by/4.0/). 